\title{
Effect of Religiosity on the Sakinah Finance Implementation and Its Impact on Family Welfare (Survey on Muslim Women Reciting Daarut Tauhid Mosque in Bandung)
}

\section{Mugy Ansyori Fauzyan, Suryana, and Aas Nurasyiah}

Economics and Islamic Finance Department, Universitas Pendidikan Indonesia Jl. Dr. Setiabudhi No. 229 Kota Bandung

\section{Abstract}

Financial problems are common to families. Mismanagement of the economy is often a source of contention between husband and wife and becomes a problem of household rifts. Good Sakinah finance is expected to neutralize the economic pressures faced by the family so as not to interfere with the interaction process that results in family welfare. This study aims to analyze the effect of religiosity on the implementation of

Corresponding Author: Mugy Ansyori Fauzyan ansyorimugy@gmail.com

Received: 10 February 2019 Accepted: 14 March 2019 Published: 28 March 2019

Publishing services provided by Knowledge E

(c) Mugy Ansyori Fauzyan et al. This article is distributed under the terms of the Creative Commons Attribution License, which permits unrestricted use and redistribution provided that the original author and source are credited.

Selection and Peer-review under the responsibility of the ICIEBP Conference Committee.

\section{S OPEN ACCESS} sakinah finance and its impact on family welfare. This study uses a correlational design with 60 Muslim women studying at the Daarut Tauhid Mosque in Bandung. Sampling is done by using a non-probability random sampling method for young and senior Muslim age groups, Muslim women studying at the Daarut Tauhid Mosque in Bandung. Based on simple linear regression, it is known that religiosity affects the implementation of sakinah finance. And other results indicate the implementation of sakinah finance affects family welfare.

\section{Keywords: Sakinah Finance, Religiosity, Family Welfare, Muslima Recitation}

\section{Introduction}

Family welfare is the hope and purpose of everyone, but the reality in the field is different from that expectation because there are still many families that are not prosperous due to several factors and among them due to economic factors (family financial management). Based on BPS data (2018) there are still many families in Indonesia that are categorized as poor / underprivileged as many as 26.5 million families in the category of underprivileged until 2017. In West Java as many as 3.77 million families are categorized as poor / underprivileged. Seeing this is a problem that must be resolved by the government and of course the community itself, in order to achieve the mandate 
of the 1945 Constitution, namely the creation of social welfare for the entire Indonesian nation.

According to Muhammadiyah Amin (2018) in 2017, the divorce rate is still relatively high, although the data does not yet exist. Divorce in 2017 there is no data yet, but if the 2016 data is 350 thousand. Based on data from the Director General of the Religious Courts of the Supreme Court in the 2014-2016 period, divorce in Indonesia has indeed continued to increase. Sudibyo Alimoeso said that there are three things that generally lie behind the divorce, namely the economic, psychological factors, and the absence of a complaint room for family problems. Economic factors are closely related to the readiness and understanding of the bride and groom to manage family finances. While psychological factors are related to the maturity or mental readiness of the bride and groom wading through the household (Muharam, 2015).

A quarrel in a household sometimes has a family financial problem. Generally, many consider family financial problems to arise due to small income. However, if traced further, the causes of family financial problems are due to weak household financial management. The results of a media study in Jakarta showed that young executives who were paid above Rp. 15 million per month, endangered by poverty in the future because he lives spree and has no investment. On the other hand, many poor families are able to deliver their children to undergraduate education because these poor families are able to manage their finances even though they are very minimal (Saktiawan, 2009).

Financial planning is deemed unnecessary with the assumption that every month the expenditure is the same or the income received is uncertain (Hakim, Sunarti, \& Herawati, 2014). Lack of knowledge about the principles of financial management and financial problems makes some families do not follow financial practices that have been recommended (Hogart \& Hilgert, 2003). Most families do not make financial records. This indicates financial planning that is not comprehensive but based on momentary or incidental needs (Joko, 2012). The importance of family finances is to achieve prosperity in the family itself in order to achieve the family's financial goals (Febriani \& Saharuddin, 2014).

Thus, even though low income is a problem, in the long run the income can be high if managed properly. But on the contrary, although high income, if not managed properly, the edges will be in a condition that is deficient (Saktiawan, 2009). Financial management is very important, then Allah SWT. and the Messenger of Allah. teach financial management such as the argument in the following Al-Qur'an and Hadith.

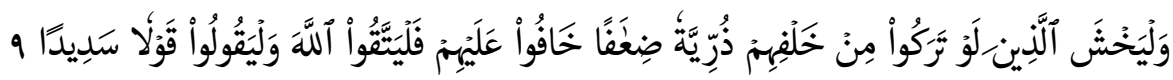


"And be afraid (of Allah) those who if they leave a weak descendant behind them who fear their welfare. Therefore, let them fear Allah, and let them speak with the right words "(Q.S. An-Nisa (4): 9).

"Will not shift a servant's foot so he will be asked about four cases (1) about his age for what he spent, (2) about his knowledge for what he practiced, (3) about his property from where he got and where he spent, and (4) about his body for what he uses "(HR. At-Tirmidhi).

In the context of Islam, asset / financial management must be carried out in the corridor of benefiting. This attitude gave birth to a stereotype that in Islam making family financial planning must aim to achieve falah (prosperous world and hereafter), avoiding the ways that maysir, gharar, usury and wrongdoing both in collecting income and in spending it, prioritizing sadaqah even though the sustenance is narrow and away from wasteful nature (Syaparuddin, 2014).

\section{Literatur Review}

In theory according to Sen in Haughton \& Khandker (2012) welfare is seen from the consumption and income approach. The higher the income will lead to higher welfare as seen from the size of their consumption. While according to Dwi in (Widyatuti, 2012) economic theories often link between high levels of welfare and higher quality of life. Based on this understanding, the concept of welfare has a narrow sense because by only seeing income as an indicator of economic prosperity means that welfare is seen as opposed to conditions of poverty.

Theoretically according to M. Quraish Shihab in (Ismatulloh, 2015) the sakinah family is a family that is calm, peaceful, happy, and prosperous, physically and spiritually, a family that has dynamic and active peace. According to Said Agil Husin al-Munawwar (2003) in accordance with the hadith of the Prophet that there are several things that become pillars of prosperous families, namely: first has a tendency to religion; second, it's easy to respect the old and love the young; third, simple in shopping; fourth, polite in socializing; fifth, always introspection; sixth, husband and wife who are loyal (righteousness and piety) to their partners; seventh, children who are dedicated to their parents; eighth, a healthy and harmonious social environment; ninth, cheap and easy to rizqy.

Rules in Islam are an important key in people's lives and policies and in an interesting purpose development in Muslim religiosity as an empirical subject in social research (El-Menouar, 2014). 
Charles Glock's in (El-Menouar, 2014) multidimensional religiosity models present a separate set of instruments from different aspects of Muslim religiosity. Glock deferred between five independent dimensions in relative terms and stated that this dimension encompassed all possible conditions of the expression of all religions found in all religions in the world.

Theoretically, according to Gitman in Krishna, Rofaida, \& Sari in Sina \& Noya (2012) that financial management is a process of planning, analyzing and controlling financial activities. One form of application of financial management is called personal financial management, namely the process of planning and financial control of individual or family units. According to Altfest (2007) Personal Finance is the study of how people develop the cash flows necessary to support their operations and provide for their well-being.

Financial management practice gives direction to families to maintain and manage the assets they have. Specifically, financial management practices are very important to improve finance in contemporary society at this time. Therefore, the examination of consumers' financial management practices is important for understanding of stratification and social reproduction in contemporary societies. On one hand, adopting strategic financial management practices opens doors to professional job markets, middle-class position, financial independence, and wealth accumulation (Leung, 2011).

According to Ahmed \& Salleh (2016) Islamic Financial Planning is financial planning to regulate personal or family finances by paying attention to aspects of philanthropy (zakat, waqf) and aims to benefit in accordance with the maqhasid of sharia.

According to Wahab (2014) Islamic Financial Planning is a current innovative concept being developed at the moment and it has a connection with the meaning of Islamic Financial Marketing which defined by Ibnu Abu Yusuf \&lbnu Taimiyyah and Ibnu Khaldun. They defined it as the creation, developing and delivery of unique customer satisfying competitive products and services at a profit to organization and customer in the lights of Islamic values and principles. In Islam, financial planning is not just merely a process of acquisition and accumulating wealth but it has a broad definition which relates to the concept of vicegerent (khalifah).

According to Tamanni \& Mukhlisin (2013) sakinah finance is how to manage finances in order to achieve the goals of maqashid syariah as a means of worship, namely by managing income, managing needs, managing dreams / wants, managing supply / deficit, managing contingency. 


\section{Methodology}

According to Sunyoto (2013) research methods are a scientific method in research by obtaining data with specific purposes and uses. The method used in this study is descriptive and explanatory methods. This method is quantitative which is used to examine the behavior of an individual or group by taking samples from one population and using a questionnaire as a data collection tool.

This study itself examines the level of influence of independent variables on the dependent variable directly and the effect of independent variables on the dependent variable through an intermediary variable in which the problems that become the core in this study do not have a dependency between one another. Then this research design is more suitable to be correlational.

The sample is representative of the study population. Population of the Muslim mosque of Daarut Tauhid mosque. Based on interviews with the Head of the DKM Daarut Tauhid Mosque in Bandung, the number of Muslim women studying the Daarut Tauhid mosque is 300 people. Therefore, to determine the sample of Muslim women studying the Daarut Tauhid Mosque in Bandung, researchers used non-probability sampling technique with the type of sample used was purposive sampling with judgment sampling technique. The characteristic of this type of sampling is that what is sampled is based on research needs with criteria determined by researchers in accordance with their needs in research (Sunyoto, 2013).

According to Rohmana (2013) linear regression analysis is used to determine the relationship of a dependent variable with an independent variable. If there is only one dependent variable and one independent variable, it is called simple linear regression analysis. Regression analysis which only consists of two variables (one dependent variable and one independent variable). This study analyzed the data using simple linear regression analysis method.

\section{Result}

In the general characteristics of respondents consisting of Muslim women studying Daarut Tauhid Mosque which will be described based on research findings such as type of age, education, employment. An explanation of the general characteristics of the respondent will describe the results of his research and explain the facts that occurred in the field. The following data will be displayed in the form of tables and pictures, as follows: 


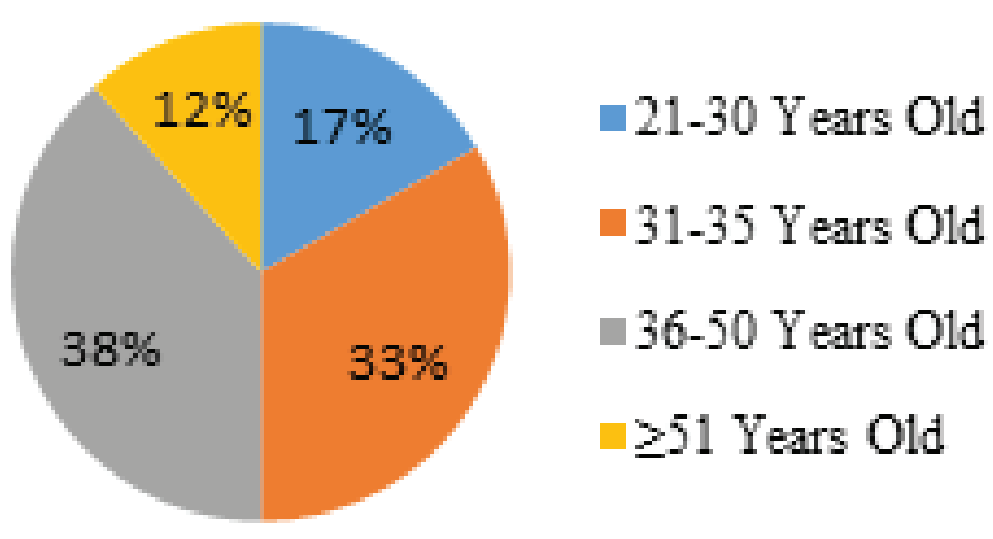

Figure 1: Percentage of Respondents by Age (Source: Respondent Answers Processing Results (2018)).

Based on age, it is dominated by the age range of 36-50 years, because many Muslim Daarut Tauhid studies are still productive. In addition to attending the recitation, many also participated in the activities of the Daarut Tauhid foundation and activities organized by the mosque. Seeing this, the age that can participate in activities optimally is between 36-50 years, because it is an adult age who has the provision of experience, knowledge and energy to participate in various activities at the Daarut Tauhid Foundation and one of them is a recitation activity at Daarut Tauhid Mosque.

Based on education dominated by high school / equivalent graduates, because there is still a lot of stigma or assumption that women do not need education too high. Just enough is enough with the knowledge of religion in the recitation, because women are the obligation that mainly takes care of the family. From these results it can be seen that the Muslim education of Daarut Tauhid studies is still low because the majority of high school graduates are down.

Based on the active duration of recitation is dominated by 6-10 years, because Daarut Tauhid Mosque was built in the early 1990s and began to be known in the early 2000s. The possibility of many Muslim women studying the Daarut Tauhid Mosque is starting to be concerned about following the recitation at the beginning of Daarut Tauhid known until now.

Based on the work dominated by the other (Housewife), because the very core role of women is taking care of the household, especially in Islam it is strongly emphasized 


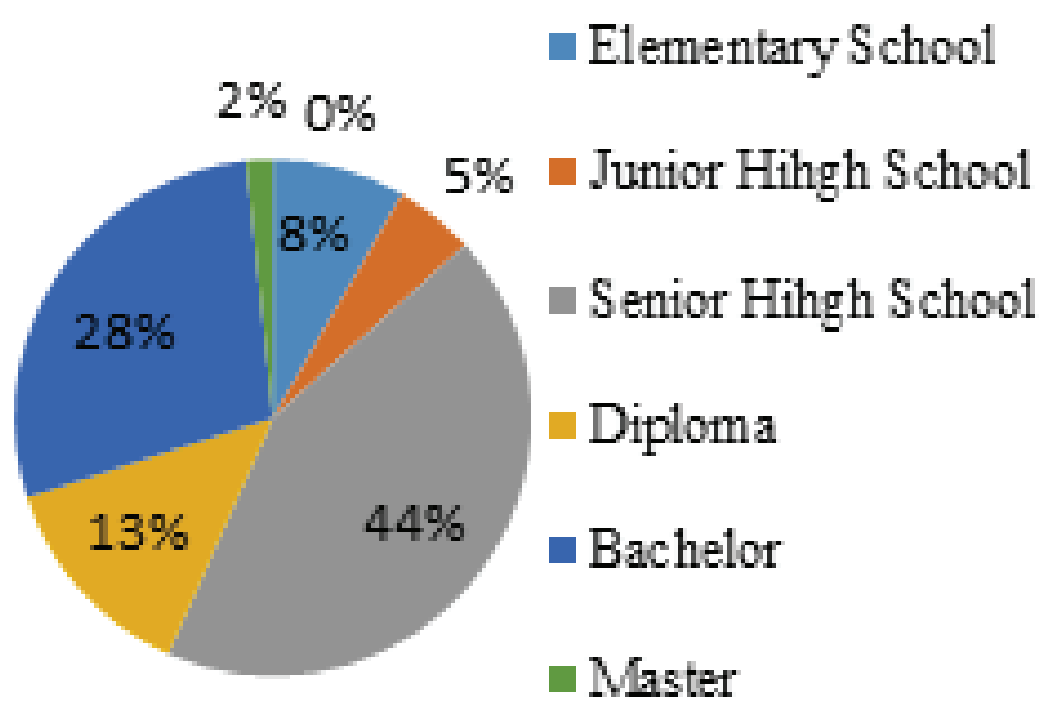

Doctorate

Figure 2: Percentage of Respondents Based on Education (Source: Respondent Answers Processing Results (2018)).

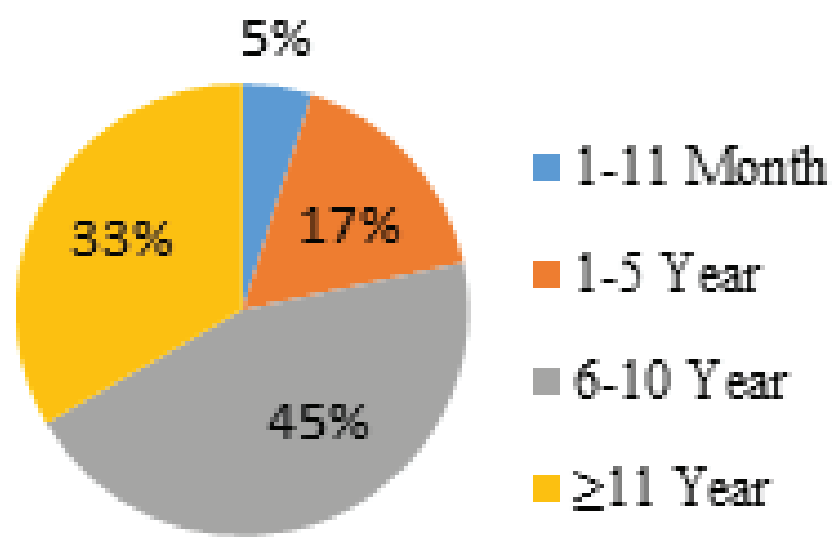

Figure 3: Percentage of Respondents Based on the Length of Active Study (Source: Respondent Answers Processing Results (2018)).

how the role of women in the family. As for women who work, do not leave the core role of women in the family.

The Sakinah Finance variable in this study was measured using seven indicators, namely income focused on halal sources, expenditure prioritizing priorities, expenditures on halal and thayib matters, contribution of zakat, infaq, shadaqah, endowments 


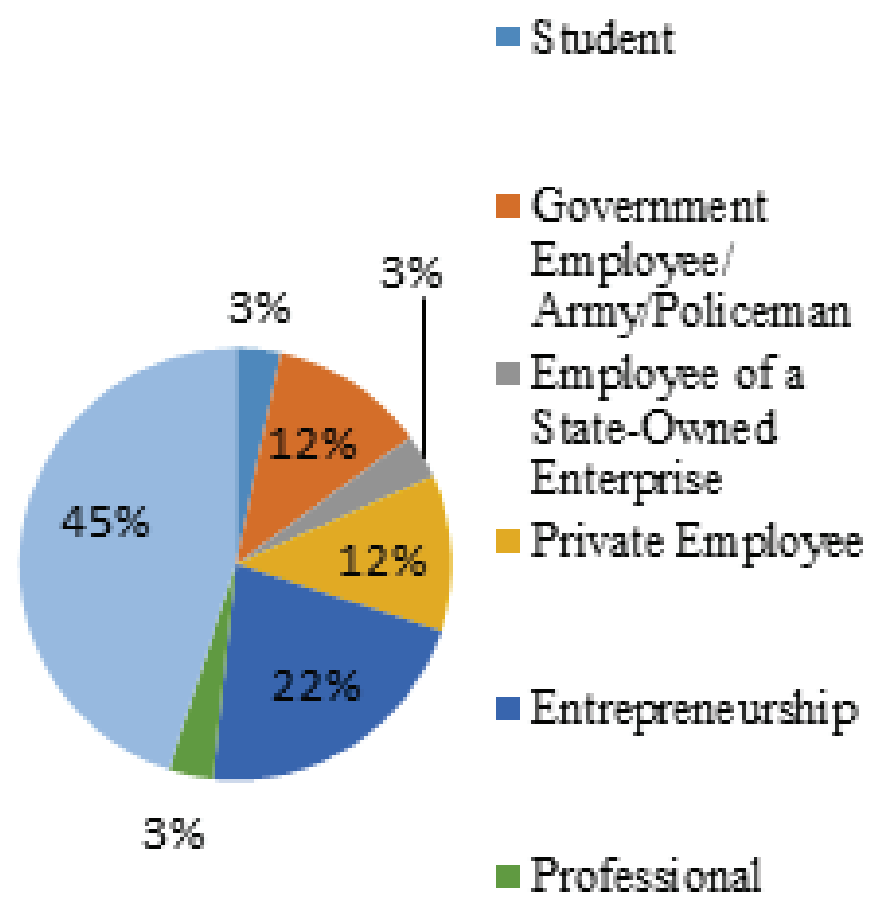

m Others

Figure 4: Percentage of Respondents by Job (Source: Respondent Answers Processing Results (2018)).

and inheritance preparation, budgeting for dreams and desires, investment, and budgeting for unexpected needs. The seven indicators are elaborated into 15 statements that are used as a measure of the variables of financial trust in Muslim women studying the Daarut Tauhid Mosque, based on calculations from 60 respondents.

Calculation of high or low categories of financial security variables. Based on the range made from the lowest value scale to the highest value as follows:

TABLE 1: Recapitulation of Respondents' Answers to Sakinah Finance.

Skala
$X>(\mu+1,0 \sigma)$
$(\mu-1,0 \sigma) \leq X \leq(\mu+1,0 \sigma)$
$X<(\mu-1,0 \sigma)$

Rentang
$X>55$
$35 \leq x \leq 55$
$X<35$

\begin{tabular}{|c|}
\hline Kategori \\
\hline Baik \\
\hline Cukup \\
\hline Kurang \\
\hline
\end{tabular}

\begin{tabular}{|c|c|}
\hline $\mathbf{F}$ & $\mathbf{R}$ \\
\hline 19 & $31,7 \%$ \\
\hline 41 & $68,3 \%$ \\
\hline 0 & $0 \%$ \\
\hline
\end{tabular}

Source: Respondent Answers Processing Results (2018) 
Based on the results of categorization it can be seen that Daarut Tauhid Muslim women have implemented well as many financial scholarships as 19 people and have implemented good financial scholarship as many as 41 people.

The Religiosity variable in this study was measured using three indicators, namely, obedience to obligations, knowledge, beliefs. The three indicators are described into nine statements that are used as a measure of the variable of religiosity at the Muslim mosque of Daarut Tauhid mosque, based on calculations from 60 respondents.

Calculation of high or low categories of religiosity variables. Based on the range made from the lowest value scale to the highest value as follows:

TABLE 2: Recapitulation of Respondents' Answers to Religiosity.

\begin{tabular}{l|c|c|c|c}
\hline Skala & Rentang & Kategori & F & R \\
\hline$X>(\mu+1,0 \sigma)$ & $X>33$ & Tinggi & 44 & $73,3 \%$ \\
\hline$(\mu-1,0 \sigma) \leq X \leq(\mu+1,0 \sigma)$ & $21 \leq X \leq 33$ & Sedang & 16 & $26,7 \%$ \\
\hline$X<(\mu-1,0 \sigma)$ & $X<21$ & Rendah & 0 & $0 \%$ \\
\hline Source: Respondent Answers Processing Results (2018) & & & \\
\hline
\end{tabular}

Based on the categorization results it can be seen that the Muslim Daarut Tauhid study which has a high level of religiosity as many as 44 people and who have a moderate level of religiosity as many as 16 people.

Variable Family Welfare in this study was measured using three indicators, namely, being able to become a model of the surrounding community, faith values, devotion and morality embedded in personal and family life and growing feelings of love in harmony, harmony and balance in family members. The three indicators are outlined into 9 statements that are used as a measure of family welfare variables in Muslim women studying the Daarut Tauhid Mosque, based on calculations from 60 respondents.

Calculation of high or low categories of family welfare variables. Based on the range made from the lowest value scale to the highest value as follows:

TABLE 3: Recapitulation of Respondents' Answers to Family Welfare.

\begin{tabular}{l|c|c|c|c|}
\hline Skala & Rentang & Kategori & F & R \\
\hline$X>(\mu+1,0 \sigma)$ & $X>33$ & Sejahtera & 49 & $81,6 \%$ \\
\hline$(\mu-1,0 \sigma) \leq X \leq(\mu+1,0 \sigma)$ & $21 \leq X \leq 33$ & Cukup Sejahtera & 11 & $18,3 \%$ \\
\hline$X<(\mu-1,0 \sigma)$ & $X<21$ & Tidak Sejahtera & 0 & $0 \%$ \\
\hline Source: Respondent Answers Processing Results (2018) & & &
\end{tabular}

Based on the categorization results it can be seen that Muslim women who study Daarut Tauhid have 49 prosperous families and have 11 prosperous families. Test 
Analysis 1 is used to determine the effect of religiosity $(X)$ on sakinah finance $(Y)$. As for the acquisition of the results of test 1 , the coefficient of determination and analysis of the model path diagram on the variables of religiosity to financial security are as follows:

TABLE 4: Results of Test Model Analysis 1.

\begin{tabular}{l|c|c|c|c|} 
Variabel & Koefisien & Std. Error & Standar Koefisien & Probabilitas \\
\hline C Religiosity (X) & $19,3960,936$ & $3,9000,108$ & 0,752 & $0,0000,000$ \\
\hline \multicolumn{2}{l}{ Source: Research Results (2018) }
\end{tabular}

Based on data processing it can be seen that religiosity affects the sakinah finance, because the probability is 0,000 less than 0.05 . Next will be discussed about the magnitude of the influence in the model analyzed. This determination coefficient uses SPSS. Here are the results of the coefficient of determination $\left(R^{2}\right)$ in this study, namely as follows:

TABLE 5: Determination Coefficient $\left(R^{2}\right)$.

\begin{tabular}{|c|c|c|c|c|}
\hline Model & $\mathbf{R}$ & R Square & Adjust R Square & $\begin{array}{l}\text { Std. Error of the } \\
\text { Estimate }\end{array}$ \\
\hline 1 & $0,752^{\partial}$ & 0,566 & 0,558 & 4,62508 \\
\hline
\end{tabular}

Based on Table 5 it is known that the coefficient of determination is 0.558 . This means that in this research model the variable religiosity $(X)$ has an effect on sakinah finance $(Y)$ of $55.8 \%$ and the remaining $44.2 \%$ is influenced by other variables not explained in this study. Based on Table 4, that variable religiosity $(X)$ to the variable sakinah finance $(Y)$ with a significance value of $0.00<0.05$ then $\mathrm{Ha}$ is accepted and $\mathrm{Ho}$ is rejected. This means that the path coefficient of the variable religiosity $(X)$ on the variable sakinah finance $(Y)$ can be stated as influential. So it can be concluded that the variable religiosity $(X)$ on the variable sakinah finance $(Y)$.

According to Muhammad (2014) shari'ah financial management is an activity of planning, organizing, staffing, implementing, and controlling financial functions guided by shari'ah principles. According to Tamanni \& Mukhlisin (2013) sakinah finance is how to manage finances in order to achieve the goals of maqashid syariah as a means of worship, namely by managing income, managing needs, managing dreams / wants, managing supply / deficit, managing contingency.

This research supports a number of previous research studies related to religiosity towards sakinah finance. Dasti \& Sitwat (2014) said that one of the financial reasons is influenced by religiosity. The higher the religiosity, the greater will be sakinah. The 
higher the level of religiosity, the higher the financial level will be (Dasti \& Sitwat, 2014). Therefore, religiosity influences sakinah finance.

By managing finances properly and correctly automatically someone gets enough in terms of worship. This is in line with the hadith of the Prophet which reads "kaida fakri takaminal kufri" which means "actually that poverty draws closer to disbelief" the opponent of fakir is sufficient and the opposite of disbelief is faith and righteousness. So when they are in finance automatically, it will bring them closer to the faith and other acts of worship. Therefore, the results of religiosity research influence the sakinah finance in accordance with the substance of the hadith.

Testing Analysis 2 is used to find out the effect of sakinah finance $(X)$ on family welfare (Z). As for the acquisition of the results of testing 2 , the coefficient of determination and analysis of the model path diagram on the variable sakinah finance towards family welfare are as follows:

TABLE 6: Results of Test Model Analysis 2.

\begin{tabular}{l|c|c|c|c|}
\hline Variabel & Koefisien & Std. Error & Standar Koefisien & Probabilitas \\
\hline C Sakinah Finance $(X)$ & $10,0450,527$ & $3,1540,059$ & 0,760 & $0,0020,000$ \\
\hline
\end{tabular}

Based on data processing it can be seen that religiosity affects the sakinah finance, because the probability is 0,000 less than 0.05 . Next will be discussed about the magnitude of the influence in the model analyzed. This determination coefficient uses SPSS. Here are the results of the coefficient of determination $\left(R^{2}\right)$ in this study, namely as follows:

TABLE 7: Determination Coefficient $\left(R^{2}\right)$.

\begin{tabular}{|c|c|c|c|c|}
\hline Model & $\mathbf{R}$ & R Square & Adjust R Square & $\begin{array}{l}\text { Std. Error of the } \\
\text { Estimate }\end{array}$ \\
\hline 1 & $0,760^{\partial}$ & 0,578 & 0,571 & 3,16056 \\
\hline
\end{tabular}

Based on Table 7 it is known that the coefficient of determination is 0.571 . This means that in this research model the variable sakinah finance $(Y)$ affects family welfare $(Z)$ by $57.1 \%$ and the remaining $42.9 \%$ is influenced by other variables not explained in this study. Based on Table 6 , that variable sakinah finance $(Y)$ affects family welfare $(Z)$ with a significance value of $0.00<0.05$ then $\mathrm{Ha}$ is accepted and $\mathrm{Ho}$ is rejected. This means that the path coefficient variable sakinah finance $(Y)$ influences the family welfare $(Z)$ 
can be stated influential. So it can be concluded that the variable sakinah finance $(\mathrm{Y})$ influences the family welfare $(Z)$.

Theoretically according to M. Quraish Shihab in (Ismatulloh, 2015) the sakinah family is a family that is calm, peaceful, happy, and prosperous, physically and spiritually, a family that has dynamic and active peace. According to Said Agil Husin al-Munawwar (2003) in accordance with the hadith of the Prophet that there are nine things that become pillars of prosperous families, namely: first has a tendency to religion; second, it's easy to respect the old and love the young; third, simple in shopping; fourth, polite in socializing; fifth, always introspection; sixth, husband and wife who are loyal (righteousness and piety) to their partners; seventh, children who are dedicated to their parents; eighth, a healthy and harmonious social environment; ninth, cheap and easy to rizqy.

Welfare according to al-Ghazali is the achievement of benefit. The benefit itself is the maintenance of the goal of 'shara' (Maqashid al-Shari'ah). Humans cannot feel inner happiness and peace but after achieving the true welfare of all humanity in the world through the fulfillment of spiritual needs and material. In order to achieve the goal of syara 'in order to realize the benefits, he outlined the sources of welfare, namely: the maintenance of religion, soul, mind, descent and wealth (Huda, 2015).

The results of the research that support this research, according to Raharjo, Puspitawati, \& Krisnatuti (2015) found that the better financial management is carried out, the higher the family welfare. Research from Rizkillah, Sunarti, \& Herawati (2015) found that the dimensions of marital satisfaction, aspects with the highest achievement were the economy and the lowest were love and intimate relationships.

The research is in line with the research of Sulastri \& Hartoyo (2014) found that subjective well-being is significantly influenced by family income, social support, and livelihood strategies. Family income has a significant positive effect on subjective wellbeing. Looking at the sakinah finance of Muslim women the Daarut Tauhid study is good because they get the knowledge of muamalah that is intense and supported by higheducated religious teachers, so the Muslim Daarut Tauhid study has good capacity. Based on this, the Muslim women of Daarut Tauhid study can implement financial schemes whose results affect the welfare of their families.

\section{Conclusion}

Based on the results of the research and discussion of the previous chapter, it can be concluded that: 
1. The implementation of sakinah finance in Muslim women studying the Daarut Tauhid Mosque in the category is quite good. Then religiosity in Muslim women studying the Daarut Tauhid Mosque is in the high category. Family welfare in Muslim women studying Daarut Tauhid Mosque in prosperous category.

2. Religiosity influences the financial security of Muslim women studying the Daarut Tauhid Mosque. In the Qur'an and hadiths explained.

"And be afraid (of Allah) those who if they leave a weak descendant behind them who fear their welfare. Therefore, let them fear Allah, and let them speak with the right words "(Q.S. An-Nisa (4): 9).

"Will not shift a servant's foot so he will be asked about four cases (1) about his age for what he spent, (2) about his knowledge for what he practiced, (3) about his property from where he got and where he spent, and (4) about his body for what he uses "(HR. At-Tirmidhi).

If you have or have good religiosity, then someone will be careful in managing their finances, where is the money obtained from and where to spend because there is accountability in the afterlife. Therefore, the results of religiosity research influence the sakinah finance in accordance with the text and substance of the Qur'anic (4): 9 verse and the hadith.

3. Implementation of sakinah finance affects family welfare. Welfare according to alGhazali is the achievement of benefit. The benefit itself is the maintenance of the goal of 'shara' (Maqashid al-Shari'ah). Humans cannot feel inner happiness and peace but after achieving the true welfare of all humanity in the world through the fulfillment of spiritual needs and material. In order to achieve the goal of syara 'in order to realize the benefits, he outlined the sources of welfare, namely: the maintenance of religion, soul, mind, descent and wealth (Huda, 2015). Muslim family welfare in Daarut Tauhid study is very prosperous. Because the family problem is an interesting theme, in recitation it is often the theme of the tausyiah which is continued. This is the provision of Muslim women studying Daarut Tauhid, in living their family life. From the frequent information about the family makes a perception for Muslim women. According to Stephen Covey in his seven habit, a perception will produce a thought from that thought into a belief, after being sure that it will be done in life, something that is done often will become a habit and habit which is carried out continuously will produce a character. Tausyiah, which is intense and comprehensive, might be a Muslim woman character in Daarut Tauhid recitation so as to form a prosperous family. 
4. The recommendations based on the results of this study are:

(a) Daarut Tauhid Muslim women should study more about the management of family finances, where now it is very much needed, Daarut Tauhid mosque DKM invites financial scholars such as Ahmad Ghazali, Hari Putra or representatives of the Financial Services Authority (OJK) because OJK also publishes many books and articles about sakinah finance.

(b) Daarut Tauhid mosque DKM brings lecturers who study more about fiqh, especially fiqh muamalah, such as Yusuf Qardhawi's halal-haram law also about families such as the fiqh sunnah by Sayyid Sabiq in order to better understand and understand the law in the frame of Islamic shariah.

(c) Researchers should then not only examine women, but also men. Because men also have a role in regulating household finances.

[1] Ahmed, H., \& Salleh, A. M. (2016). Inclusive Islamic Financial Planning: A Conceptual Framework. International Journal of Islamic and Middle Eastern Finance and Management.

[2] Altfes, L. J. (2007). Personal Financial Planning. Singapore: McGraw Hill.

[3] al-Munawwar, S. H. (2003). Agenda Generasi Intelektual: Ikhtiar Membangun Masyarakat Madani. Jakarta: Pena Madani.

[4] Amin, M. (2018, Januari Minggu). Ratusan Ribu Kasus Perceraian Terjadi dalam Setahun. Retrieved Juni Senin, 2018, from Republika: http://www.republika.co. id/berita/dunia-islam/islam-nusantara/18/01/21/p2w4v9396-ratusan-ribu-kasusperceraian-terjadi-dalam-setahun

[5] BPS. (2018). Konsep Kemiskinan. Retrieved Juni 5, 2018, from https://www.bps.go. id/subject/23/kemiskinan-dan-ketimpangan.html\#subjekViewTab1

[6] Dasti, R., \& Sitwat, A. (2014). Development of a Multidimensional Measure of Islamic Spirituality (MMS). Journal of Muslim Mental Health.

[7] El-Menouar, Y. (2014). The Five Dimensions of Muslim Religiosity. Results of an Empirical Study. methods, data, analyses.

[8] Febriani, E. M., \& Saharuddin. (2014). Status Pekerjaan Pada Peternakan Sapi Perah Dan Kaitannya Dengan Tingkat Kesejahteraan. 20.

[9] Hakim, F. A., Sunarti, E., \& Herawati, T. (2014). Manajemen Keuangan Dan Kepuasan Keuangan Istri Pada Keluarga Dengan Suami Istri Bekerja. IImu Keluarga \& Konseling. 
[10] Haughton, J., \& Khandker, S. R. (2012). Pedoman Tentang Kemiskinan dan Ketimpangan. Jakarta: Salemba Empat.

[11] Hogart, J. M., \& Hilgert, M. A. (2003, July). Household Financial Management: The Connection

Between Knowledge And Behavior. Federal Reserve Bulletin.

[12] Isdarmawan, A., Tirta, I. M., \& Dewi, Y. S. (2013). Pola - Pola Jalur Pada Path Analysis untuk Analisis Faktor-Faktor yang Berpengaruh terhadap Nilai UN SMA di Kabupaten Lumajang. Kadikma, Vol. 4, No. 1, 87-102.

[13] Ismatulloh, A. (2015). Konsep Sakinah, Mawaddah dan Rahmah dalam Al-Qur'an (Perspektif Penafsiran Kitab Al-Qur'an dan Tafsirnya). Pemikiran Hukum Islam.

[14] Joko, F. A. (2012). Pola Konsumsi, Investasi, dan Proteksi Sebagai Indikator Perencanaan Keuangan Keluarga (Studi Pada Masyarakat Kabupaten Sidoarjo). 4446.

[15] Leung, A. (2011). Financial management practices and social reproduction. Qualitative Market Research: An International Journal.

[16] Muharam. (2015, Juni 30). Tingginya Perceraian Di Indonesia.

[17] Raharjo, I. T., Puspitawati, H., \& Krisnatuti, D. (2015). Tekanan Ekonomi, Manajemen Keuangan, Dan Kesejahteraan Pada Keluarga Muda. Ilmu Keluarga dan Konseling.

[18] Rizkillah, R., Sunarti, E., \& Herawati, T. (2015). Kualitas Perkawinan Dan Lingkungan Pengasuhan Pada Keluarga Dengan Suami Istri Bekerja. Ilmu Keluarga \& Konseling.

[19] Rohmana, Y. (2013). Ekonometrika Teori dan Aplikasi dengan Eviews. Bandung: Laboratorium Pendidikan Ekonomi dan Koperasi, FPEB, UPI Bandung.

[20] Saktiawan, I. R. (2009). Islamic Financial Planning: Dialog Taktis Menyiasati Krisis. Bandung: PT Salamadani Pustaka Semesta.

[21] Sina, P. G., \& Noya, A. (2012). Pengaruh Kecerdasan Spiritual Terhadap Pengelolaan Keuangan Pribadi. Jurnal Manajemen.

[22] Sulastri, S., \& Hartoyo. (2014). Pengaruh Dukungan Sosial Dan Strategi Nafkah Terhadap Kesejahteraan Subjektif Keluarga Usia Pensiun. IImu Keluarga \& Konseling.

[23] Sunyoto, D. (2013). Metode dan Instrumen Penelitian (untuk ekonomi dan bisnis). Yogyakarta: CAP (Center for Academic Publishing Service).

[24] Syaparuddin. (2014). Pengelolaan Keuangan Keluarga Secara Profesional Dalam Mewujudkan Keluarga Sakinah. Al-Risalah-Jurnal Hukum Keluarga Is/am.

[25] Tamanni, L., \& Mukhlisin, M. (2013). Sakinah Finance; Solusi Mudah Mengatur Keuangan Keluarga Is/ami. Solo: PT. Tiga Serangkai Pustaka Mandiri. 
[26] Wahab, A. A. (2014). A Review of Islamic Financial Planning Process in Oman and Nigeria. International Journal of Management Sciences.

[27] Widyatuti, A. (2012). Analisis Hubungan Antara Produktivitas Pekerja dan Tingkat Pendidikan Pekerja Terhadap Kesejahteraan Keluarga di Jawa Tengah Tahun 2009. Economics Development Analysis. 